MINERALOGIA, 42, No 1: 7-17 (2011)

DOI: 10.2478/v10002-011-0002-y

www.Mineralogia.pl

MineRALOGICAL Society of Poland

Polskie TOWARZYSTWO MINERALOgICZNE

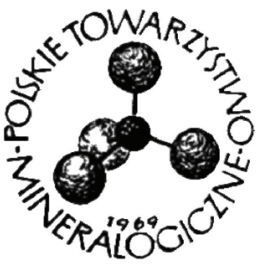

Original paper

\title{
Geochemical background - an environmental perspective
}

\author{
Agnieszka GAŁUSZKA ${ }^{1 *}$, Zdzisław M. MIGASZEWSKI ${ }^{1}$ \\ Jan Kochanowski University, Institute of Chemistry, Geochemistry and the Environment Div., \\ 15G Świętokrzyska St., 25-406 Kielce, Poland; e-mails: aggie@ujk.kielce.pl; zmig@ujk.kielce.pl \\ * Corresponding author
}

Received: October 30, 2010

Received in revised form: June 30, 2011

Accepted: August 10, 2012

Available online: March 26, 2012

\begin{abstract}
This article presents the concept of geochemical background from an environmental perspective. The idea of establishing the typical concentrations of elements in various environmental compartments, proposed by exploratory geochemists almost 50 years ago was important for the detection of anomalous element concentrations, thus providing a basic tool in the search for new mineral deposits. At present, the knowledge of the geochemical background of hazardous elements is essential for: defining pollution, identifying the source of contamination, and for establishing reliable environmental quality criteria for soils, sediments and surface waters. The article presents geochemical methods of evaluation of anthropogenic influence on the environment and discusses the problem of defining and understanding the term "geochemical background" and related terms in environmental sciences. It also briefly presents methods of geochemical background evaluation based on the results of environmental sample analyses. It stresses the role of geochemical background in our understanding of environmental pollution and pollution prevention.
\end{abstract}

Key-words: geochemical background, environmental quality criteria, anthropogenic impact, pollution source identification

\section{Introduction}

Introduction of large amounts of chemical substances into the environment by human activity has caused enrichment of many elements in surface waters, sediments and soils, particularly in industrial areas. Studying these anomalies, called "anthropogenic anomalies", became an essential part of geochemical and environmental research. The first 
application of the concept of geochemical background to geochemistry was for geochemical prospecting purposes (Hawkes, Webb 1962). The role of geochemical background was to provide information on the distribution of geochemical anomalies, which were important in searching for new mineral deposits. The knowledge of the typical (normal, average) element concentrations in a specific area is also essential for environmental studies. The concept of the use of geochemical background in environmental sciences has emerged in the early $21^{\text {st }}$ century, when many review articles on this thematic problem have been published (e.g. Matschullat et al. 2000; Reimann, Garret 2005; Reimann et al. 2005; Gałuszka 2006; 2007a).

The meaning of geochemical background in environmental sciences differs from its traditional sense used in exploratory geochemistry. In general, this difference is directly related to the source of the geochemical anomaly in question. In geochemical prospecting methods, the source of an anomaly was not important. What really mattered was the possibility of the use of a recorded anomaly in searching for exploitable mineral deposits. In environmental studies a key issue is to find the anthropogenic influence on the environment, manifested by the presence of an anthropogenic anomaly (Selinus, Esbensen, 1995), and the differentiation between natural and human-derived sources of pollutants is vital. Another important dissimilarity between these two approaches to the problem of geochemical background is that different elements have to be taken into account when searching for new mineral deposits (principal ore constituents, such as $\mathrm{Au}, \mathrm{Ag}$ or pathfinder elements, such as $\mathrm{As}, \mathrm{Bi}$, or $\mathrm{Sb}$ ), or conducting environmental studies (mostly constituents of anthropogenic pollution, e.g. $\mathrm{Cd}, \mathrm{Pb}, \mathrm{Hg}$, or $\mathrm{Zn}$ ).

The present environment compartments are a complex combination of natural and anthropogenic elements. Although it is easy to point out the pollution sources of human activity, manifested, for instance, by roads, buildings, or wastes, however, it is very difficult to precisely delineate anthropogenic from natural pollution levels in the environment. In the concept of geochemical background in environmental sciences, the results of chemical analyses are used to detect and assess the scale of anthropogenic pollution. In most of the methods applied for geochemical background evaluation, anthropogenic anomalies are understood as enrichment of environmental samples in a given substance and the lack of such anomalies are regarded as geochemical background.

Much geochemical background research is focused on trace elements as pollutants. Of special importance are the studies, which aim at establishing geochemical background of elements originating from both industrial and geogenic sources (e.g. As) (Portier 2001; Zillioux 2001) or potentially toxic trace elements in mineralized areas (Kelley, Taylor 1997; Martínez et al. 2007), because their high concentrations in the environment may adversely affect the wildlife and humans. Many organic pollutants originate from natural and anthropogenic sources, but no plausible methodology of geochemical background evaluation for these substances has thus far been proposed. The major problem is that organic pollutants are both bio- and photo-degradable, thus their concentrations in environmental samples are more variable in time than are the concentrations of trace elements. 


\section{The meaning of "geochemical background" and related terms}

Historically, the first attempts to assess the enrichment of elements in environmental samples were made by geochemists on the basis of comparison between the element concentration in a sample with the average concentration of the element in the upper continental crust. As early as 1889, an American geochemist, F. W. Clarke established weighted averages of elemental composition of various rocks exposed at the Earth's surface. These concentrations are known in geochemistry as "the /clarke values" (Rudnick, Gao 2003). Another approach in determining the average composition of the upper crust is to measure concentrations of elements in fine-grained clastic sedimentary deposits. The best known example is the average shale value of elements published by Turekian and Wedepohl (1961).

Considering the differences in the meaning of the term "geochemical background" in exploratory geochemistry and environmental geochemistry, there are two approaches to defining this term. The earliest definition of geochemical background was focused on differentiating between normal and anomalous concentrations of substances in the environment. This approach was adequate for the purpose of geochemical prospecting and exploratory geochemistry, because the main objective of such studies was in general searching for positive anomalies. As examples of such approaches the following definitions of "geochemical background" may be quoted:

(1) "the normal abundance of an element in barren earth material" (Hawkes, Webb 1962).

(2) "the normal concentration of a given element in a material under investigation such as rock, soil, plants, and water" (Bates, Jackson 1984).

Matschullat et al. (2000) presented a definition of geochemical background used in environmental sciences: "a relative measure to distinguish between natural element or compound concentrations and anthropologically-influenced concentrations in real sample collectives". In another definition proposed by Gałuszka (2006), geochemical background is "a theoretical natural concentration range of a substance in a specific environmental sample (or medium), considering its spatial and temporal variability".

A wide use of the concept of geochemical background for environmental purposes caused some misconceptions about the understanding of this and related terms (Reimann, Garret 2005; Gałuszka 2007b). Some authors use different variants of the term "geochemical background", usually to stress the origin of the substance (source) and its sink (receptor) in the environment. A few examples of such cases are discussed in more detail by Reimann and Garret (2005): "natural background", "ambient background", "preindustrial background" and by Gałuszka (2007b): "anthropogenic background", "area background", "naturally occurring background", and "pedogeochemical background". It should also be mentioned that there are two terms related to "geochemical background", which are often used as synonyms of this term, but their use is unjustified. These terms are: "threshold value" and "baseline". "Threshold value" signifies the upper limit of geochemical background range, whereas "baseline" is the present concentration of chemical substance in a contemporary environmental sample. 


\section{Geochemical methods of anthropogenic influence assessment}

It is obvious that man has changed the environment since the beginning of human civilization. Recently, a new term "Anthropocene", relating to this phenomenon, was coined to stress the large scale of anthropogenic influence on the environment (Zalasiewicz et al. 2010). An exact date for the beginning of the Anthropocene has not been established. Most of the scientists agree that the dynamic increase of human activity and introduction of large amounts of pollutants into the environment started at the turn of the $18^{\text {th }}$ century during the so-called Industrial Revolution in Great Britain. When discussing geochemical background concepts, the results of chemical analyses of samples representing the preindustrial period are often regarded as representing the true geochemical background (historical aspect of the direct method - for details see the next section).

Geochemistry offers various methods for assessing anthropogenic influences. One of them is the use of geochemical calculations. When conducting studies on trace element concentrations in different environmental samples, several geochemical parameters may be established. One of the most commonly used is enrichment factor (EF), in which the element concentration and the reference element in the sample are compared to the Clarke or world average shale values, according to the following formula (Reimann, de Caritat 2005):

$$
\mathrm{EF}=\frac{A_{\mathrm{e}} \cdot B_{c}}{A_{c} \cdot B_{e}}
$$

where:

$A_{e}$ - element concentration in environmental sample

$B_{e}-$ reference element concentration in environmental sample

$A_{c}$ - Clarke value or average shale value of the element

$B_{c}-$ Clarke value or average shale value of reference element

This procedure is also called "normalization". The EFs can be used to differentiate crustal from non-crustal origins of a given element. It is assumed that EF values close to 1 are indicative of crustal origins whereas those $>10$ are considered to be of non-crustal sources.

Reference (or conservative) elements are those whose concentrations are so abundant in the earth's crust that anthropogenic influences do not change them substantially, or else they are inert in biogeochemical cycles. The most often used reference elements are: $\mathrm{Si}, \mathrm{Al}$, $\mathrm{Fe}, \mathrm{Sc}, \mathrm{Cs}$, and $\mathrm{Ti}$. It is worth mentioning that sometimes total organic carbon (TOC) and granular composition of solid samples are used in normalization procedure, by analogy with conservative elements. An example of the use of EFs for the assessment of anthropogenic influence on bottom sediments from the South China Sea was given by Shazili and others (2007).

Another factor, which was introduced to classify the quality of environmental samples, is contamination factor (CF). For its calculation, a mean concentration of a given element in at least 5 samples is divided by pre-industrial concentration of the element (Håkanson 1980): 


$$
\mathrm{CF}=\frac{C_{i}}{C_{n}}
$$

where:

$C_{i}-$ mean content of element in samples taken from at least 5 sampling sites

$C_{\mathrm{n}}$ - pre-industrial concentration of element

It is interesting to note that in this case, the "pre-industrial concentration" is usually equated to the Clarke value (Loska et al. 2004). CFs values below 1 indicate low contamination, those in the range of 1-3 - moderate contamination, 3-6 - considerable contamination, and $>6$ very high contamination. An example of the use of contamination factor (together with enrichment factor and geoaccumulation index) is provided by Loska and others (2004) from their study of soils in Suszec commune (southern Poland).

Pollution load index (PLI) uses the concentration factors of different elements in the same sample, and is obtained as a concentration factor (ConcF) of each element with respect to the background value (Tomlinson et al. 1980):

$$
\mathrm{PLI}=\sqrt[n]{\operatorname{ConcF}_{1} \cdot \operatorname{ConcF}_{2} \cdot \ldots \cdot \text { ConcF }_{n}}
$$

where: $C o n c F$ is a quotient of the concentration of the element in the sample and its background concentration. The geochemical background concentration is understood as the world average shale value or Clarke value (Tomlinson et al. 1980). An interesting example of calculation of pollution load indices was published by Galán and others (2002). According to this study, after a catastrophic mining spill in Spain, soils from the vicinity of the river bed and in the upper parts of the sediment profiles had elevated pollution load indices even after remediation operations.

Geochemical background values are also used to calculate the geoaccumulation index $\left(\mathrm{I}_{\mathrm{geo}}\right)$, which categorizes seven classes of contamination of environmental samples (Müller 1969):

where:

$$
\mathrm{I}_{\mathrm{geo}}=\log _{2} \frac{C_{e}}{1.5 \cdot G B}
$$

$C_{e}$ - concentration of the examined element in the sample

$G B$ - geochemical background concentration

According to $I_{\text {geo }}$ values, there are 7 classes of the sample pollution, varying from 0 (unpolluted) to 6 (extremely polluted).

In the study of identification of anthropogenic pollution sources, the relationship between the source, the process of pollutant distribution (route), and the receptor is of special importance. At least four scenarios of this relation may be distinguished (Mudge 2008):

(1) One source - one process - one receptor;

(2) One source - many processes - one receptor;

(3) Many sources - many processes - one receptor;

(4) Many sources - many processes - many receptors.

It is relatively easy to study the first and the second cases, in which a chemical substance may be directly attributed to its source, but it is not the typical situation and 
usually it is limited to synthetic compounds. In the most common scenarios (cases 3 and 4), the enrichment of an environmental sample by a certain chemical is caused by different sources (both present and historical). Identification of the contribution of these sources needs more detailed research. In some cases a rogue source of the contaminant should be considered (e.g. illegal discharges, fugitive emissions or discharges, fly-tipping, etc.) (Mudge 2008). Such situations have both legal and financial implications according to "polluter pays" principle and this is why a great effort is being made to improve the techniques for distinguishing between pollution sources.

A very useful tool in the present anthropogenic influence assessment is the study of technogenic (industrial) particulates. The shape as well as the chemical and mineral compositions of particulates allow for evaluation of the relative contribution of different sources to atmospheric pollution. As early as in 1976, Manecki (1976) indicated that the mineral composition of atmospheric dust may be attributable to a specific source. The chemical analyses of airborne particulates may also provide a very important information on their origin. Trace element content (e.g. rare earth elements) and stable isotope composition $\left({ }^{34} \mathrm{~S} /{ }^{32} \mathrm{~S},{ }^{206} \mathrm{~Pb} /{ }^{207} \mathrm{~Pb},{ }^{87} \mathrm{Sr} /{ }^{86} \mathrm{Sr},{ }^{143} \mathrm{Nd} /{ }^{144} \mathrm{Nd}\right)$ of particulates are often determined in identification of anthropogenic sources (Grobéty et al. 2010).

An invaluable tool for the study of anthropogenic pollution sources is provided by stable isotope analysis. For instance, the comparison of stable sulfur isotopes in different environmental samples with those in industrial samples allows to estimate the influence of local pollution sources on the environment (Górka et al. 2008; Krouse, Grinenko 1991). Stable lead isotopes ${ }^{205} \mathrm{~Pb} /{ }^{204} \mathrm{~Pb}$ are often used in the study of anthropogenic pollution (Jaakkola et al. 1983; Church 1993; Church et al. 1999). Differences in the ratio ${ }^{53} \mathrm{Cr} /{ }^{52} \mathrm{Cr}$ in environmental samples are determined to identify $\mathrm{Cr}$ from anthropogenic sources (Izbicki et al. 2008). Nitrogen ${ }^{15} \mathrm{~N} /{ }^{14} \mathrm{~N}$ and oxygen ${ }^{18} \mathrm{O} /{ }^{16} \mathrm{O}$ isotopes allow to track pollution sources of nitrate (Silva et al. 2002). The study of stable carbon ${ }^{13} \mathrm{C} /{ }^{12} \mathrm{C}$ and chlorine ${ }^{35} \mathrm{Cl} /{ }^{37} \mathrm{Cl}$ isotopes are often performed to define sources of persistent organic pollutants (e.g. polycyclic aromatic hydrocarbons, chlorinated compounds, gasoline oxygenates) (Slater 2003; Philp 2007).

Some elements and their isotopes are used as geochemical tracers in the assessment of anthropogenic influences on the environment. In the study of the river water quality, differentiating between point and diffuse pollution sources is an important issue. In this case geochemical tracers may be applied. Substances used as geochemical tracers have to meet certain criteria: they should not react with waterborne elements or solids (should be conservative) and their concentrations have to be constant in time (they should not be biodegradable). As an example, the use of boron and its isotopes (Barth 1998), and gadolinium may be given (Petelet-Giraud et al. 2009). Both boron and gadolinium are ideal geochemical tracers which may be applied for the assessment of the quality of urban river systems. Boron is used in detergents and its concentrations in urban wastewater are high, as it is not removed in traditional wastewater treatment plants (it is conservative in rivers). Gadolinium is used in the form of gadopentetic acid as a contrast agent in magneticresonance imaging (MRI). This complex remains stable in water (is not biodegradable). It has been established that this element displays excessive concentrations above natural levels in European rivers (Petelet-Giraud et al. 2009). 


\section{Methods of geochemical background evaluation in environmental studies}

There is no general agreement among geochemists on how geochemical background values should be established. Currently, there are three methods in use: direct, indirect and integrated (Fig. 1).

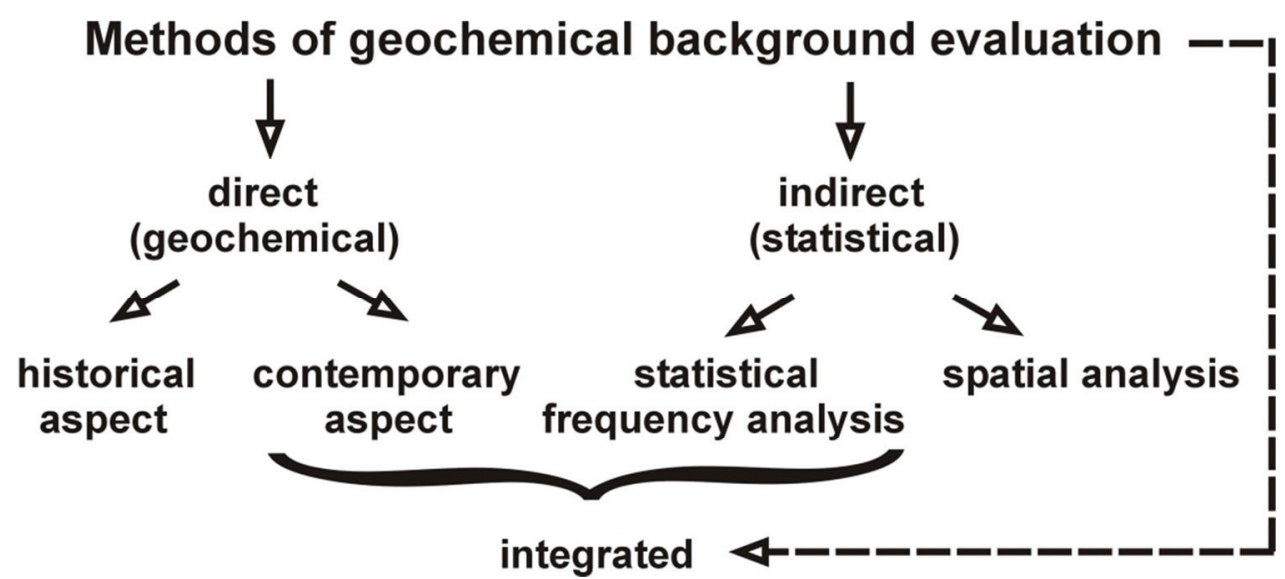

Fig. 1. Division of methods used in geochemical background evaluation.

The direct, also called geochemical methods, use the mean or median values (fixed values) obtained in the study of samples representing pre-industrial period (historical aspect) or collected in pristine areas (contemporary aspect) (Crommentuijn et al. 2000; Baize, Sterckeman 2001; Horckmans et al. 2005). The examples of historical samples are isotopically dated deep limnic, marine, overbank, and river sediments, glacial ice cores as well as archival plants from herbaria, deep soil horizons, or tree rings. However, the use of deep sediments or deep soil horizons as unaffected by the human activity has been criticized in geochemical literature (Reimann, de Caritat 2005) because the depletion of these environmental compartments in many elements results from their natural properties, not from the lack of anthropogenic pollution. It is also questionable whether "pristine areas" are really free of anthropogenic pollution. Geochemical background should be understood as a range, not a single value. Nevertheless, despite some difficulties, direct methods have their advantages. The most important one is that the results represent the real world data and are not subjected to any processing. The opponents of these methods find them unattractive because of subjective sample/study area selection criteria, high costs, heavy laboratory workload, and the necessity of expert knowledge (Matschullat et al. 2000).

The indirect methods, also known as statistical (Matschullat et al. 2000), use graphical and computational techniques to eliminate the outliers from the distribution of chemical analysis results. Historically, the first formula for geochemical background assessment was the mean \pm 2 standard deviations and this formula is still being applied in some statistical techniques (e.g. $4 \sigma$-outlier test, iterative $2 \sigma$-technique). In indirect methods of geochemical 
background evaluation two approaches can be distinguished (Fig. 1). The first and most often used is based on the analysis of statistical frequency (Lima 2008). All the techniques which aim at the outlier elimination from original distribution may be given as examples

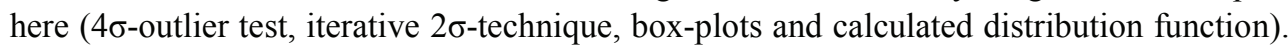
The other approach is represented by spatial analysis (Lima 2008). In this type of investigation visualization of geochemical data plays the most important role. Analysis of geochemical maps enable delineating geochemical anomalies from background concentrations. Advantages of the statistical approach lay within its methodology - robust, clear, and precise. A feature which may be an advantage, but for some scientists it may seem to be disadvantage, is a wide selection of techniques available for geochemical background evaluation. Most of the techniques may be applied with user-friendly and widely accessible computer programs. Opponents of the indirect methods show that in these methods the natural processes are not fully appreciated, the analytical quality criteria are not considered in interpretation of the results, and the geochemical background is understood in the meaning of traditional exploration and prospecting use. It is also questionable whether anthropogenic influence always causes enrichment of the environment in a given substance. From a geochemical point of view, some pollutants are remobilized from soils by anthropogenic activity (Bäckström et al. 2004; Norrström 2005) being depleted, not enriched in this environmental compartment.

An alternative approach to geochemical background evaluation is represented by the integrated method combining both previously discussed methods, which means that the samples are collected in pristine areas and the results are subjected to statistical calculations. It was used for the first time to establish geochemical background values of samples collected in the Holy Cross Mountains (Gałuszka 2007a). The most important advantage of the integrated method is that it does not require substantial data processing because the samples collected in relatively pristine areas do not contain many outliers (if any) and express natural geochemical variability.

\section{Geochemical background in environmental quality criteria}

Geochemical background values should be taken into account when establishing quality criteria for soils, sediments and waters. If the regulatory levels are based on toxicological studies only (risk assessment) and do not refer to geochemical data, they would not be possible to be met in cases when geochemical background values are elevated. Reimann and Garret (2005) give the example of this case. In Austria, arsenic concentrations in soils are 6 to 20 times above the world average and according to legal regulations, Austrian soils over a large part of the country ought to be remediated. Such actions would be useless and very expensive, besides, they will not solve the problem if soil contamination is caused by geogenic sources. In the Polish environmental quality standards for soils (The regulation of the Minister of the Environment on the soil quality standards 2002) it is stated that the accepted quality criteria for soils recognize high anomalous concentrations of pollutants derived only from anthropogenic sources and if the pollution is of natural origin, no reclamation is needed. However, this document says nothing about distinguishing natural from non-natural levels of a given substance. Such imprecise criteria in the environmental law can cause enforcement problems. 
The report prepared by the European Commission (Carlon 2007), entitled "Derivation methods of soil screening values in Europe. A review and evaluation of national procedures towards harmonization" discusses the problem of incoherence of soil quality standards in European Union (EU) countries. A review of the proposed screening values by different EU members for potentially unacceptable risk (residential soil-use) for metals and metalloids reveal that large differences between these values (for instance by a factor of 900 for tin $-1 \mathrm{mg} / \mathrm{kg}$ d.w. (dry weight) in Italy, $900 \mathrm{mg} / \mathrm{kg}$ d.w. in the Netherlands) do not correspond to the data derived from regional geology or geochemistry. The differences in the number of soil screening values proposed by each country are also dubious, ranging from less than 20 to 234 (an average of 60) substances. Such chaos prevailing in environmental law is unacceptable.

\section{Concluding remarks and the outlook for the future}

The most important tasks for the future, regarding geochemical background and its role in environmental studies, concern three areas: terminology, methodology and application. First, there is a strong need for systematization of terminology as the term "geochemical background" and related terms are differently understood and used by various authors. Second, one method of geochemical background should be chosen and used for environmental purposes. Last but not least, only reliable geochemical background values enable the establishment of objective environmental quality criteria. The knowledge of geochemical background concentrations, especially of toxic trace elements, may help risk managers in the initiation of remedial actions, which have serious economic and environmental consequences.

Geochemists were the first scientists who developed the idea of geochemical background in their studies. Geochemical knowledge on the distribution and migration of elements in and between different environmental compartments is crucial in understanding pollution that originates from natural and anthropogenic sources. This is the reason why the role of geochemistry in environmental studies is so important and its significance for the study of pollution should increase in the future.

\section{References}

Bäckström, M., Karlsson, S., Bäckman, L., Folkeson, L., \& Lind, B. (2004). Mobilization of heavy metals by deicing salts in a roadside environment. Water Research, 38, 720-732. DOI: 10.1016/j.watres.2003.11.006.

Baize, D., \& Sterckeman, T. (2001). Of the necessity of knowledge of the natural pedo-geochemical background content in the evaluation of the contamination of soils by trace elements. Science of the Total Environment, 264, 127-139. DOI: 10.1016/S0048-9697(00)00615-X.

Barth, S. (1998). Application of boron isotopes for tracing sources of anthropogenic contamination in groundwater. Water Resources, 32(3), 685-690. DOI: 10.1016/S0043-1354(97)00251-0.

Bates, R. L., \& Jackson, J. A. (Eds.) (1984). Dictionary of Geological Terms. New York: Anchor Books. A Division of Random House, Inc.

Carlon, C. (Ed.) (2007). Derivation methods of soil screening values in Europe. A review and evaluation of national procedures towards harmonization. European Commission. Ispra. Joint Research Centre. 
Church, S. E. (1993). Geochemical and lead-isotope data from stream and lake sediments, and cores from the upper Arkansas River drainage: Effects of mining at Leadville Colorado on heavy-metal concentration in the Arkansas River. U.S. Geol. Surv. Open-File Report 93-534.

Church, S. E., Alpers, C. N., Vaughn, R. B., Briggs, P. H., \& Slotton, D. G. (1999). Use of Lead Isotopes as Natural Tracers of Metal Contamination. In G. S. Plumlee \& M. J. Logsdon (Eds.). The Environmental Geochemistry of Mineral Deposits, Part A. Processes, Techniques, and Health Issues. Reviews in Economical Geology 6A. (pp. 567-583). Littleton, CO: Society of Economic Geologists.

Clarke, F. W. (1889). The relative abundance of the chemical elements. Bulletin of the Philosophical Society of Washington, XI, 131-142.

Crommentuijn, T., Sijm, D., De Bruijn, J., van den Hoop, M., van Leeuwen, K., \& van de Plassche, E. (2000). Maximum permissible and negligible concentrations for metals and metalloids in the Netherlands, taking into account background concentrations. Journal of Environmental Management, 60, 121-143. DOI: 10.1006/jema.2000.0354.

Galán, E., González, I., \& Fernández-Caliani, J. C. (2002). Residual pollution load of soils impacted by the Aznalcóllar (Spain) mining spill after clean-up operations. The Science of the Total Environment, 286(1-3), 167-179. DOI: 10.1016/S0048-9697(01)00974-3.

Gałuszka, A. (2006). Methods of determining geochemical background in environmental studies. Problems of Landscape Ecology, XVI/1, 507-519. (in Polish with English summary).

Gałuszka, A. (2007a). A review of geochemical background concepts and an example using data from Poland. Environmental Geology, 52, 861-870. DOI: 10.1007/s00254-006-0528-2.

Gałuszka, A. (2007b). Different approaches in using and understanding the term "geochemical background" practical implications for environmental studies. Polish Journal of Environmental Studies, 16(3), 389-395.

Górka, M., Jędrysek, M. O., \& Strąpoć, D. (2008). Isotopic composition of sulphates from meteoric precipitation as an indicator of pollutant origin in Wrocław (SW Poland). Isotopes in Environmental and Health Studies, 44, 177-188. DOI: 10.1080/10256010802066307.

Grobéty, B., Gieré, R., Dietze, V., Stille, P. (2010). Airborne particles in the urban environment. Elements, 6(4), 229-234. DOI: 10.2113/gselements.6.4.229.

Håkanson, L. (1980). Ecological risk index for aquatic pollution control. A sedimentological approach. Water Research, 14, 975-1001.

Hawkes, H. E, \& Webb, J. E. (1962). Geochemistry in mineral exploration. New York: Harper.

Horckmans, L., Swennen, R., Deckers, J., \& Maquil, R. (2005). Local background concentrations of trace elements in soils: a case study in the Grand Duchy of Luxemburg. Catena, 59, 279-304. DOI: 10.1016/j.catena.2004.09.004.

Izbicki, J. A., Ball, J. W., Bullen, T. D., \& Sutley, S. J. (2008). Chromium, chromium isotopes and selected trace elements, western Mojave Desert, USA. Applied Geochemistry, 23, 1325-1352. DOI: 10.1016/j.apgeochem.2007.11.015.

Jaakkola, T., Heinonen, O. J., Keinonen, M., Salmi, A., \& Miettinen, J. K. (1983). Use of ${ }^{206} \mathrm{~Pb} /{ }^{204} \mathrm{~Pb}$ isotope ratio in lichens, air filter, incinerator ash and gasoline samples as pollution source indicator. International Journal of Mass Spectrometry and Ion Physics, 48, 347-350. DOI: 10.1016/0020-7381(83)87099-5.

Kelley, K. D., \& Taylor, C. D. (1997). Environmental geochemistry of shale-hosted Ag-Pb-Zn massive sulfide deposits in northwest Alaska: natural background concentrations of metals in water from mineralized areas. Applied Geochemistry, 12, 397-409. DOI: 10.1016/S0883-2927(97)00009-7.

Krouse, H. R., \& Grinenko, V. A. (Eds.) (1991). Stable Isotopes: Natural and Anthropogenic Sulphur in the Environment. New York, ..., Singapore: John Wiley \& Sons.

Lima, A. (2008). Evaluation of geochemical background at regional and local scales by fractal filtering technique: Case studies in selected Italian areas. In B. De Vivo, H. E. Belkin \& A. Lima (Eds.) Environmental Geochemistry. Site characterization, Data Analysis and Case Histories. (pp. 135-152). Amsterdam: Elsevier.

Loska, K., Wiechuła, D., \& Korus, I. (2004). Metal contamination of farming soils affected by industry. Environment International, 30, 159-165. DOI: 10.1016/S0160-4120(03)00157-0.

Manecki, A. (1976). Aeromineralogy - Mineralogy of Atmospheric Dust. Mineralogia Polonica, 7, 91-97.

Martínez, J., Llamas, J., de Miguel, E., Rey, J., \& Hidalgo, M. C. (2007). Determination of the geochemical background in a metal mining site: example of the mining district of Linares (South Spain). Journal of Geochemical Exploration, 94, 19-29. DOI: 10.1016/j.gexplo.2007.05.001.

Matschullat, J., Ottenstein, R., \& Reimann, C. (2000). Geochemical background - can we calculate it? Environmental Geology, 39, 990-1000. DOI: 0.1007/s002549900084. 
Mudge, S. M. (2008). Environmental forensics and the importance of source identification. In: R. E. Hester \& R. M. Harrison. (Eds.) Environmental Forensics (pp. 1-16). Cambridge: Royal Society of Chemistry.

Müller, G. (1969). Index of geoaccumulation in sediments of the Rhine River. Geojournal, 2, 108-118.

Norrström, A. C. (2005). Metal mobility by de-icing salt from an infiltration trench for highway runoff. Applied Geochemistry, 20, 1907-1919. DOI: 10.1016/j.apgeochem.2005.06.002.

Petelet-Giraud, E., Klaver, G., \& Negrel, P. (2009). Natural versus anthropogenic sources in the surface- and groundwater dissolved load of the Dommel river (Meuse basin): Constraints by boron and strontium isotopes and gadolinium anomaly. Journal of Hydrology, 369, 336-349. DOI: 10.1016/j.jhydrol.2009.02.029.

Philp, R. P. (2007). The emergence of stable isotopes in environmental and forensic geochemistry studies: a review. Environmental Chemistry Letters, 5, 57-66. DOI: 10.1007/s10311-006-0081-y.

Portier, K. M. (2001). Statistical issues in assessing anthropogenic background for arsenic. Environmental Forensics, 2, 155-160. DOI: 10.1006/enfo.2001.0051.

Reimann, C., \& de Caritat, P. (2005). Distinguishing between natural and anthropogenic sources of element in the environment: regional geochemical surveys versus enrichment factors. Science of the Total Environment, 337, 91-107. DOI: 10.1016/j.scitotenv.2004.06.011.

Reimann, C., Filzmoser, P., \& Garret, R. G. (2005). Background and threshold: critical comparison of methods of determination. Science of the Total Environment, 346, 1-16. DOI: 10.1016/j.scitotenv.2004.11.023.

Reimann, C., \& Garret, R. G. (2005). Geochemical background - concept and reality. Science of the Total Environment, 350, 12-27. DOI: 10.1016/j.scitotenv.2005.01.047.

Rudnick, R.L. \& Gao, S. (2003). The Composition of the Continental Crust. In: H. D. Holland \& K. K. Turekian. (Eds.) Treatise on Geochemistry. Vol. 3 (pp. 1-64). Oxford: Elsevier-Pergamon.

Selinus, O. S., \& Esbensen, K. (1995). Separating anthropogenic from natural anomalies in environmental geochemistry. Journal of Geochemical Exploration, 55, 55-66. DOI: 10.1016/0375-6742(95)00034-8.

Shazili, N. A. M., Kamaruzzaman, B. Y., Antonina, N. A., Zauyah, S., Bidai, J., Shamsudin, A. A., \& Kamil, A. R. (2007). Interpretation of anthropogenic input of metals in the South China Sea bottom sediments of Terengganu (Malaysia) coastline using Al as a reference element. Aquatic Ecosystem Health \& Management, 10(1), 47-56. DOI: 10.1080/14634980701201681.

Silva, S. R., Ging, P. B., Lee, R. W., Ebbert, J. C., Tesoriero, A. J., \& Inkpen E. L. (2002). Forensic applications of nitrogen and oxygen isotopes of nitrate in an urban environment. Environmental Forensics, 3, 125-130. DOI: $10.1006 /$ enfo.2002.0086.

Slater, G. F. (2003). Stable isotope forensics - when isotopes work. Environmental Forensics, 4, 13-23. DOI: $10.1080 / 15275920303485$.

The regulation of the minister of the environment on the soil quality standards. (2002). Journal of the Acts (Dziennik Ustaw) of September 9, No. 165, item 1359.

Tomlinson, D. L., Wilson, J. G. Harris C. R. \& Jeffrey D. W. (1980). Problems in the assessments of heavy metal levels in estuaries and formation of a pollution index. Helgol Meeresunters, 33, 566-575.

Turekian, K. K. \& Wedepohl, K. H. (1961). Distribution of the elements in some major units of the earth's crust. Geological Society of America Bulletin, 72, 175-191.

Zalasiewicz, J., Williams, M., Steffen, W., \& Crutzen, P. (2010). The New World of the Anthropocene. Environmental Science \& Technology, 44(7), 2228-2231. DOI: 10.1021/es903118j.

Zillioux, E. J., (2001). Arsenic background definition: introduction and objectives. Environmental Forensics, 2 , 115-116. DOI: 10.1006/enfo.2001.0045. 